\title{
The Schoolwide Enrichment Model: A Comprehensive Plan for the Development of Talents and Giffedness
}

\author{
Joseph Renzulli* \\ The artist is nothing without the gift, but the gift is nothing without the work.
}

(Émile Zola)

\section{Abstract}

The Schoolwide Enrichment Model (SEM) is widely implemented as an enrichment program used with academically gifted and talented students and a general enrichment approach for all schools interested in developing the strengths and talents of all learners. The major goal of the SEM is the application of gifted education pedagogy to total school enrichment and joyful learning. The SEM provides enriched learning experiences and higher learning standards for all children through three goals: developing talents in all children, providing a broad range of enrichment experiences for all students, and providing advanced level follow-up opportunities for young people based on their strengths and interests. The SEM focuses on enrichment for all students through high levels of engagement and the use of enjoyable and challenging learning experiences that are constructed around students' interests, learning styles, and preferred modes of expression.

Keywords: Enrichment; Gifted; Total School Improvement.

* Diretor do The National Research Center On The Gifted and Talented. Storrs, Connectiut, United States of America. 


\section{Modelo de enriquecimento para toda a escola: um plano abrangente para o desenvolvimento de talentos e superdotação}

\section{Resumo}

O Modelo de Enriquecimento para toda a Escola (SEM) é amplamente implementado como um programa de enriquecimento utilizado com estudantes superdotados e talentosos academicamente e uma abordagem de enriquecimento geral para todas as escolas interessadas em desenvolver os pontos fortes e talentos de todos os educandos. O principal objetivo do SEM, é a aplicação da pedagogia educacional para alunos superdotados ao enriquecimento total da escola e a uma aprendizagem desfrutável. O SEM proporciona experiências de aprendizagem enriquecidas e padróes de aprendizagem mais elevados para todas as crianças por meio de três objetivos: desenvolver talentos em todas as crianças, oferecer uma ampla gama de experiências de enriquecimento para todos os estudantes e proporcionar oportunidades de acompanhamento em nível avançado para os jovens com base em seus pontos fortes e interesses. O SEM focaliza o enriquecimento para todos os estudantes por meio de elevados níveis de engajamento e o uso de experiências de aprendizagem desfrutáveis e desafiadoras que são construídas em torno dos interesses, estilos de aprendizagem e modos de expressão preferidos dos estudantes.

Palavras-chave: Enriquecimento; Superdotados; Melhoria de toda a Escola.

\section{History and Underlying Theory}

All learning exists on a continuum and learning theories that guide what happens in most classrooms range from deductive, didactic, and prescriptive approaches to learning at one end of the continuum to inductive, investigative, and inquiry oriented approaches at the other. This continuum exists for learners of all ages from toddlers to doctoral students - and it exists in all areas of curricular activity. The continuum also exists for learning that takes place in the world outside-the-classroom, the kind of experiences that young people pursue in extracurricular activities and that adults pursue as they go about acquiring new skills for their jobs, hobbies, or special interests. Both models of learning and teaching are valuable in the overall process of schooling, and a well-balanced school program must make use of both approaches as well as combined approaches between the two ends of the continuum.

The majority of what happens in standards-driven curriculum and the standardized test approach to accountability and assessment, however, favors the deductive end of the continuum and the use of highly prescriptive material to guide instruction. The result of overemphasis on this type of learning has been a good deal of boredom, disengagement, monotony, and a lack of genuine enjoyment for learning on the parts of many students. The "information factory" approach to schooling also has favored 
lower level skills such as rote memory, repetition, and instructional practices that sustain endless text consumption, test prep, and repeated coverage of factual material.

The major purpose of the Schoolwide Enrichment Model (SEM) is to infuse into the regular curriculum an expanded continuum of services opportunities, resources, and teacher support that blend more enrichment and investigative learning into the total school experience.

These services, which vary in depth and complexity according to individual student strengths, are targeted on our most gifted and talented students, and the model also expands enrichment opportunities for a broader range of students in the general school population. The model seeks to minimize elitism by labeling services rather than students, and by promoting a radiation of excellence throughout the entire school. Defining a specific range of service delivery options, and focusing on a pedagogy or "brand" of learning that is based on inductive and investigative theories makes it possible to accomplish these goals. The SEM is not designed to replace or "throw out" everything in the curriculum to which a school is already committed. Rather the purpose is to make learning more interesting, exciting, and enjoyable, to promote the development of higher level thinking skills, and to create a school atmosphere that values and practices what we call investigative learning.

Investigative learning is based on the ideas of a small number of philosophers, theorists, and researchers (e.g., John Dewey, Albert Bandura, Howard Gardner, Maria Montessori, Philip Phenix, Robert Sternberg, E. Paul Torrance, Alfred North Whitehead ${ }^{1}$ ). The work of these theorists, coupled with our own research and program development activities, has given rise to four principles that serve as a rationale for the SEM:

1. Each learner is unique, and, therefore, all learning experiences must be examined in ways that take into account the abilities, interests, learning styles and preferred modes of expression of the individual.

2. Learning is more effective when students enjoy what they are doing. Consequently, learning experiences should be constructed and assessed with as much concern for enjoyment as for content acquisition goals.

3. Learning is more meaningful and enjoyable when content (i.e., knowledge) and process (i.e., thinking skills, methods of inquiry) are learned within the context of a real and present problem. Therefore, attention should be given to opportunities to personalize student choice in problem selection, the relevance of the problem for individuals and groups who share a common interest in the problem, and strategies for assisting students in personalizing problems they might choose to study.

4. Some formal and prescriptive instruction may be used in investigative learning, but a major goal of this approach is to enhance knowledge, thinking skill acquisition, and creative productivity by examining all topics for opportunities to infuse investigative instructional practices. 
The pedagogy of prescription and text consumption has unintentionally withheld from many students the exact kinds of 21st Century thinking skills that are necessary for successful participation in higher education and today's growing global economy. Unlike prescriptive, Pavlovian pedagogy, the SEM capitalizes on student engagement, enjoyment and creative productivity. Accountability for the truly educated mind in today's knowledge-driven economy should first and foremost attend to students' ability to acquire and apply the following skills:

- plan a task and consider alternatives

- monitor one's understanding and the need for additional information

- identify patterns, relationships, and discrepancies in information

- generate reasonable arguments, explanations, hypotheses, and ideas using appropriate information sources, vocabulary, and concepts

- draw comparisons and analogies to other problems

- formulate meaningful questions

- apply and transform factual information into usable knowledge

- rapidly and efficiently access just-in-time information and selectively extract meaning from that information

- extend one's thinking beyond the information given

- detect bias, make comparisons, draw conclusions, and predict outcomes

- apportion time, schedules, and resources

- apply knowledge and problem solving strategies to real world problems

- work effectively with others

- communicate effectively in different genres, languages, and formats

- derive enjoyment from active engagement in the act of learning

- creatively solve problems and produce new ideas

There was a time when the pursuit of these principles and skills were considered to be idealistic but unattainable because of the diversity of learner characteristics and the amount of time that teachers can reasonably devote to even small amounts of instructional differentiation. The advent of technology (discussed below), however, has now placed opportunities for greater personalization of learning opportunities within easy reach.

\section{Theoretical Underpinnings of the SEM}

\section{The Dual Goal of Developing Academic Giftedness and Creative Productivity}


Present efforts to develop giftedness are based on previous studies dealing with human abilities (STERNBERG, 1984, 1988, 1990; STERNBERG \& DAVIDSON, 1986; THORNDIKE, 1921) and general conclusions from current research on giftedness (STERNBERG \& DAVIDSON, 2005). These studies provide a critical background for this discussion of the SEM. First, giftedness is not a unitary concept. There are many manifestations of gifts and talents and therefore single definitions cannot adequately explain this multifaceted phenomenon. The confusion about present theories of giftedness has led many researchers to develop new models for explaining this complicated concept, but most agree that giftedness is developed over time and that culture, abilities, environment, gender, opportunities, and chance contribute to the development of gifts and talents (STERNBERG \& DAVIDSON, 2005).

The SEM focuses on the development of both academic and creative-productive giftedness. Creative-productive giftedness describes those aspects of human activity and involvement where a premium is placed on the development of original material and products that are purposefully designed to have an impact on one or more target audiences. Learning situations designed to promote creative-productive giftedness emphasize the use and application of information (content) and thinking skills in an integrated, inductive, and real-problem-oriented manner. In the SEM, traditional academic gifts are developed using curriculum compacting, acceleration, differentiated instruction and various forms of academic enrichment. Our focus on creative productivity transforms the role of the student from that of a learner of lessons to one of a firsthand inquirer who can experience the joys and frustrations of creative productivity (RENZULLI, 1977). It also transforms the role of the teacher from an administrator of text consumption to what we call the-guide-on-the-side. This approach is quite different from the development of giftedness that tends to emphasize deductive learning, content acquisition, and the storage, and retrieval of information. In other words, creative-productive giftedness enables children to work on issues and areas of study that have personal relevance and can be escalated to appropriately challenging levels of investigative activity.

Why is creative-productive giftedness important enough to question the traditional approach that been used to select students for gifted programs on the basis of test scores? Why do some people want to rock the boat by challenging a conception of giftedness that can be numerically defined by simply giving a test? The answers to these questions are simple and yet compelling. A review of research literature (NEISSER, 1979; REIS \& RENZULLI, 1982; RENZULLI, 1978, 1986, 2005) tells us that there is much more to identifying human potential than the abilities revealed on traditional tests of intelligence, aptitude, and achievement. Furthermore, history tells us it has been the creative and productive people of the world, the producers rather than consumers of knowledge who have been recognized in history as "truly gifted" individuals. Accordingly, the SEM integrates both opportunities for academic giftedness, as well as creative productive giftedness.

\section{Three Ring Conception of Giftedness}

Longitudinal research supports this distinction between academic giftedness and creative/productive giftedness. Perleth, Sierwald, and Heller (1993) found di- 
fferences between students who demonstrated creative/productive as opposed to traditional academic giftedness. The SEM is based on Renzulli's (1978) "three ring" conception of creative productive giftedness, which defines gifted behaviors rather than gifted individuals. This conception encompasses three interrelated components (see Figure 1) and is described as follows:

Gifted behavior consists of behaviors that reflect an interaction among three basic clusters of human traits - above average ability, high levels of task commitment, and high levels of creativity. Individuals capable of developing gifted behavior are those possessing or capable of developing this composite set of traits and applying them to any potentially valuable area of human performance. Persons who manifest or are capable of developing an interaction among the three clusters require a wide variety of educational opportunities and services that are not ordinarily provided through regular instructional programs. (RENZULLI \& REIS, 1997, p. 8).

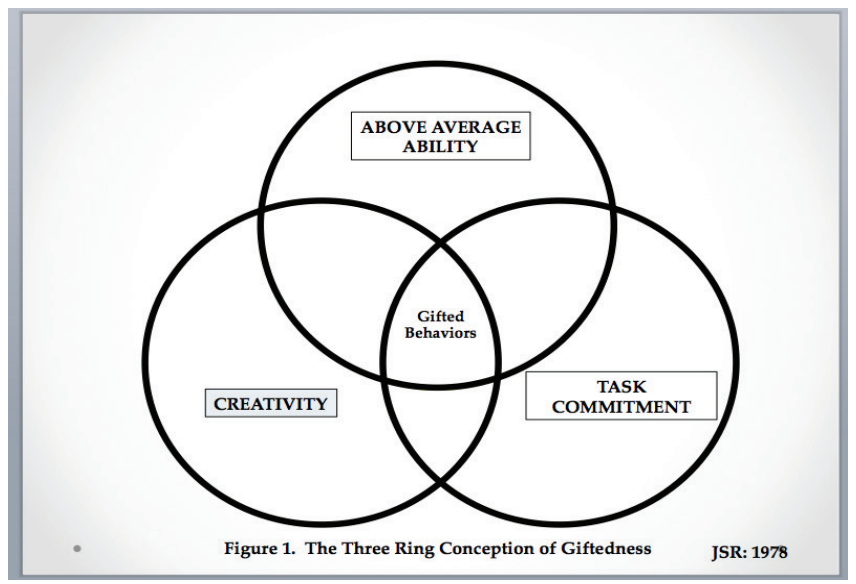

Most of the confusion and controversy surrounding the definitions of giftedness can be placed into perspective if we examine a few key questions. Is giftedness or creativity an absolute or a relative concept (AMABILE, 1983)? That is, is a person either gifted or not gifted (the absolute view), or can varying degrees of gifted behaviors be developed in certain people, at certain times, and under certain circumstances (the relative view)? Is giftedness or creativity a static concept (i.e., you have or you don't have it) or is it a dynamic concept (i.e., it varies within persons, cultures, and among learning/performance situations)?

These questions have led us to advocate a fundamental change in the ways we believe that the concept of giftedness should be viewed. For 30 years, we have advocated labeling the services students receive rather than labeling the students. We believe that a shift should occur from an emphasis on the traditional concept of "being gifted" (or not being gifted) to a concern about the development of gifted and creative behaviors in students who have high potential for benefiting from special educational opportunities, as well as the provision of some types of enrichment for all students. 
This change in terminology may also provide the flexibility in both identification and programming endeavors that encourages the inclusion of at-risk and underachieving students in our programs. Our ultimate goal is the development of a total school enrichment program that benefits all students and concentrates on making schools places for talent development for all young people.

\section{The Enrichment Triad Model}

The Triad Model (RENZULLI, 1977), the curricular basis of the SEM, was originally designed as a gifted program model to encourage creative productivity on the parts of young people by exposing them to various topics, areas of interest, and fields of study; and to further train them to apply advanced content, process-training skills, and investigative methodology training to self-selected areas of interest using three types of enrichment. The original Triad Model (See Figure 2) was originally implemented in programs designed for academically talented and gifted students. An argument was made, however, that Types I and II Enrichment should be made available to larger groups of students; and the ways in which young people responded to these general enrichment experiences should determine the nature and extent of follow-up opportunities. This approach is commonly referred today as performance -based identification.

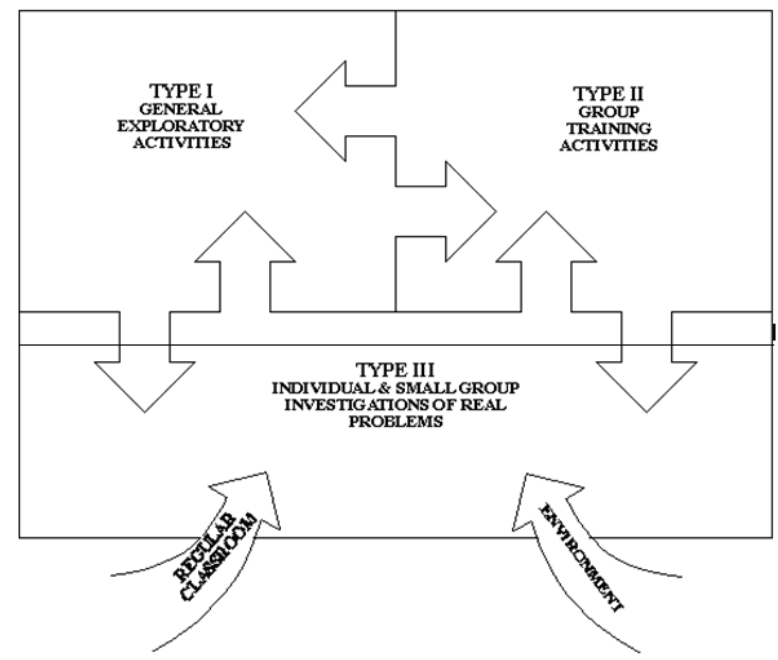

Figure 2. The enrichment triad model.

In the Triad Model, Type I Enrichment is designed to expose students to a wide variety of disciplines, topics, occupations, hobbies, persons, places, and events that are not ordinarily be covered in the regular curriculum. In schools using this approach, an enrichment team of parents, teachers, and students often organizes and plans Type I experiences by arranging human and media resources to provide these kinds of exposure. Type I enrichment is mainly designed to stimulate new interests 
leading to Type II or III follow-up on the parts of students who become motivated by Type I experiences. Type I enrichment can be provided for general groups, or for students who have already expressed an interest in the topic area.

Type II enrichment includes materials and methods designed to promote the development of thinking and feeling processes. Some Type II enrichment is general, and usually provided to groups of students in their classrooms or in enrichment programs. This general Type II training includes the development of (a) creative thinking and problem solving, critical thinking, and affective processes; (b) a wide variety of specific learning how-to-learn skills; (c) skills in the appropriate use of advanced-level research and reference materials; and (d) written, oral, and visual communication skills. Other Type II enrichment is specific, as it cannot be planned in advance and usually involves advanced instruction in an interest area selected by the student. For example, students who become interested in botany after a Type I would pursue further training in this area by reading advanced content in botany, learning about some of the methods that botanists actually use as they go about experimenting, gathering data, and carrying our their work (Type II Enrichment) and designing, planning, and carrying out their own plant experiments (Type III Enrichment). More advanced methodological training should be provided for those whose interests continue to grow and want to go further with more advanced experiments in plant research (Renzulli, 1982).

Type III enrichment involves students who become interested in pursuing a self-selected area and are willing to commit the time and effort necessary for advanced content acquisition and process training in which they assume the role of a first-hand inquirer. The goals of Type III enrichment are:

- providing opportunities for applying interests, knowledge, creative ideas and task commitment to a self-selected problem or area of study;

- acquiring advanced level understanding of the knowledge (content) and methodology (process) that are used within particular disciplines, artistic areas of expression and interdisciplinary studies;

- developing authentic products that are primarily directed toward bringing about a desired impact upon a specified audience;

- developing self-directed learning skills in the areas of planning, organization, resource utilization, time management, decision making and self-evaluation, and,

- the development of task commitment, self-confidence, and feelings of creative accomplishment.

Type III products can be completed by individuals or small groups of students and they are always based on students' interests, even if the teacher helped create the interest through Type I or other kinds of interest provoking experiences. A book written by a fifth grade student named Gretchen from Haynes School in Sudbury, MA, provides one example of a Type III study. Gretchen had two passionate interests as a fifth grader: the literature of Louisa May Alcott and cooking. Gretchen had read all of Louisa May Alcott's books and identified in each book, any specific food 
mentioned. She researched the recipes of the time that would have been used to make the food (such as buckwheat cakes), field-tested each recipe (including making substitutions for ingredients no longer available), and created an original cookbook. Gretchen spent a year and a half working on a cookbook that combined vignettes of scenes from Little Women and Little Men with many authentic 19th century recipes for making the foods described in the novels. The Louisa May Alcott Cookbook was accepted and became the first book contracted by Little Brown with a child author. In Gretchen's Type III, both the process she used and the final product involved high levels of creative engagement and clear evidence of creative work.

While the enrichment triad Model helped students identified as gifted flourish, we became increasingly interested in identification procedures that would include more academically talented and creative students who could excel and would benefit from participating in Enrichment Triad based programs.

\section{The Schoolwide Enrichment Model (SEM)}

The Enrichment Triad Model serves as the theoretical and curricular basis for the SEM that is currently implemented in a variety of settings, including gifted programs, enrichment programs, magnet and charter schools and theme schools. In the SEM, a talent pool of approximately $10-15 \%$ below the top 5\% are also candidates for supplementary enrichment opportunities. These well above average students are identified through a variety of multiple criteria including: achievement tests, teacher nominations, assessment of potential for creativity and task commitment, outstanding performance in a particular area of interest as well as alternative pathways such as self-nomination, parent nomination, etc.). High achievement tests and/or IQ test scores automatically include a student in the talent pool, enabling those students who are underachieving in their academic schoolwork to be included.

Once students are identified for the talent pool, they are eligible for several kinds of services. First, interest and learning styles assessments are used with talent pool students, in the development of a Total Talent Portfolio for each student. Informal and formal methods are used to identify and assess students' interests and to encourage students to further develop and pursue these interests in various ways. Learning style preferences include: projects, independent study, teaching games, simulations, peer teaching, computer-assisted instruction, lecture, drill and recitation, and discussion. Second, curriculum compacting and other forms of differentiation and curricular modification are provided to all eligible students when the regular curriculum is adjusted. This elimination or streamlining of curriculum enables above average students to avoid repetition of previously mastered work and guarantees mastery while simultaneously finding time for more appropriately challenging activities (REIS, BURNS, \& RENZULLI, 1992; RENZULLI, SMITH, \& REIS, 1982). A form, entitled the Compactor, (RENZULLI \& SMITH, 1978) is used to document which content areas have been compacted and what alternative work has been substituted. Third, a series of enrichment opportunities organized around the Enrichment Triad Model offers three types of enrichment experiences including enrichment clusters. Types and II are offered to all students; and highly positive responses to these 
general enrichment experiences are uses as "performance based assessment" that may result in having students revolve into Type III Enrichment opportunities.

The SEM (1997) has three major goals that are designed to challenge and meet the needs of high potential, high ability and gifted students, and at the same time, provide challenging learning experiences for all students. These goals are: (a) to maintain and expand a continuum of special services that will challenge students with demonstrated superior performance or the potential for superior performance in any and all aspects of the school and extracurricular program; (b) to infuse into the general education program a broad range of activities for high-end learning that will challenge all students to perform at advanced levels, and allow teachers to determine which students should be given extended opportunities, resources, and encouragement in particular areas where superior interest and performance are demonstrated; (c) to preserve and protect the positions of gifted education specialists and any other specialized personnel necessary for carrying out these goals.

The SEM, outlined in Figure 3, has three service delivery components that provide services to students, including the Total Talent Portfolio, Curriculum Modification and Differentiation, and Enrichment Teaching and Learning. These three services are delivered to the regular curriculum, a continuum of special services, and a series of enrichment clusters.

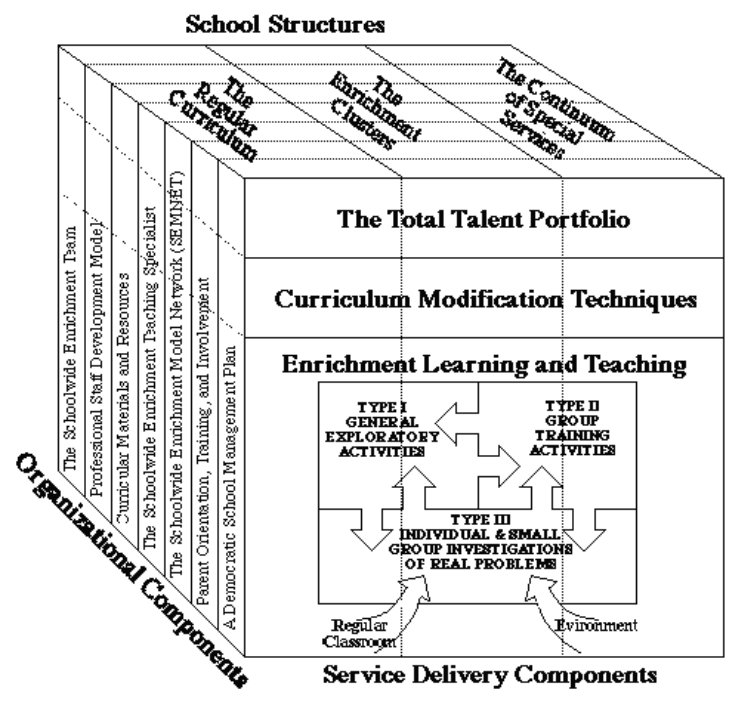

Figure 3 - The Schoolwide Enrichment Model 


\section{The Total Talent Portfolio}

In the SEM, teachers help students better understand four dimensions that allow for differentiation of their learning opportunities. These dimensions are: Academic strength areas, interests, learning, and preferred modes of expression. This information, focusing on their strengths rather than deficits, is compiled in a management form called the "Total Talent Portfolio" that can be subsequently used to make decisions about talent development opportunities in general education classes, enrichment clusters, and/or in the continuum of special services. The major purposes of the Total Talent Portfolio are: (a) to collect information about students' strengths on a regular basis; (b) to classify this information into the general categories of abilities, interests, and learning and expression styles; (c) to periodically review and analyze the information in order to make decisions about providing opportunities for enrichment experiences in the general education classroom, the enrichment clusters, and the continuum of special services; and (d) to use this information to make decisions about acceleration and enrichment in school and in later educational, personal and career decisions. This expanded approach to identifying talent potentials is essential if we are to make genuine efforts to include a broader, more diverse group of students in enrichment programs. This approach is also consistent with the more flexible conception of developing gifts and talents that has been a cornerstone of the SEM, addressing concerns for promoting more equity in special programs.

\section{Curriculum Modification \& Differentiantion Techniques}

The second service delivery component of the SEM is a series of curriculum modification techniques that can: (a) adjust levels of required learning so that all students are challenged, (b) increase the number of in-depth learning experiences, and (c) introduce various types of enrichment into regular curricular experiences. The procedures that are used to carry out curriculum modification include curriculum differentiation strategies, such as curriculum compacting, and increased use of greater depth into regular curricular material (Renzulli, 1994; Reis et al., 1993). Curriculum Compacting is an instructional differentiation technique designed to make appropriate curricular adjustments for students in any curricular area and at any grade level, through (a) defining the goals and outcomes of a particular unit or segment of instruction, (b) determining and documenting which students already have mastered most or all of a specified set of learning outcomes, and (c) providing replacement strategies for material already mastered through the use of instructional options that enable a more challenging and productive use of the student's time. An example of how compacting is used is best represented in the form, "The Compactor" that serves as both an organizational and record keeping tool (see Figure 4). 


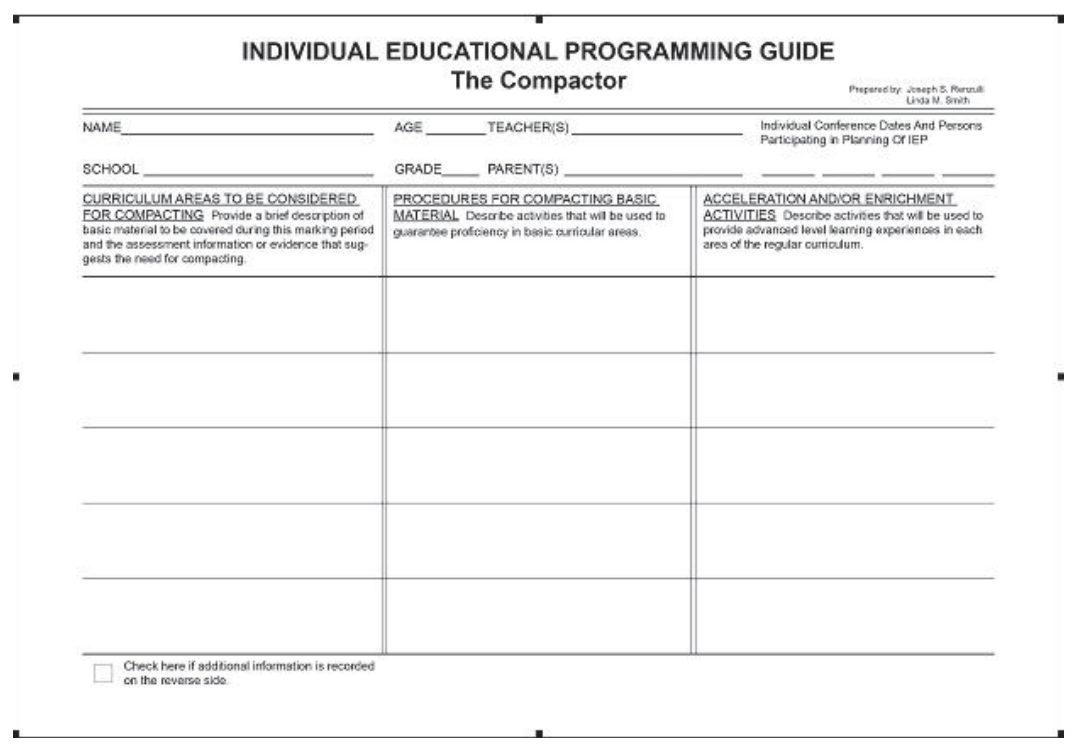

Figure 4: The Compactor

Teachers should fill out one compactor form per student. The form can also be used for small groups of students who are working at approximately the same level (e.g., a reading or math group). The Compactor is divided into three sections:

- The first column should include information on learning objectives and student strengths in those areas. Teachers should list the objectives for a particular unit of study, followed by data on students' proficiency in those objectives, including test scores, behavioral profiles and past academic records.

- In the second column, teachers should detail the assessment tools or procedures they select, along with test results. The pretest instruments can be formal measures, such as pencil and paper tests, or informal measures, such as performance assessments based on observations of class participation and written assignments.

- Column three is used to record information about acceleration or enrichment options; in determining these options, teachers must be aware of students' individual interests and learning styles. We should never simply replace compacted regular curriculum work with more drill and practice. If for example, a student loves working on science fair projects, that option may be used to replace material that has been compacted from the regular curriculum. We should also be careful to help monitor the challenge level of the material that is being substituted. We want students to understand the nature of effort and challenge, and we must ensure that we are not simply replacing the compacted material with basic reading or work that is too easy. We should also consider the compatibility of student interests and learning styles when we replace the work that has been compacted. 
The ultimate goal of learning guided by these principles is to replace dependent and passive learning with independence and engaged learning. Although all but the most conservative educators will agree with these principles, much controversy exists about how these (or similar) principles might be applied in everyday school situations. A danger also exists that these principles might be viewed as yet another idealized list of glittering generalities that cannot be manifested easily in schools that are entrenched in the deductive model of learning. Developing a school program based on these principles is not an easy task. Over the years, however, we have achieved success by gaining faculty, administrative, and parental consensus on a small number of easy-to-understand concepts and related services, and by providing resources and training related to each concept and service delivery procedure. Numerous research studies and field tests (RENZULLI \& REIS, 1994; GUBBINS, 1995) in schools with widely varying demographics have been carried out and are summarized at our web site (http://www.gifted.uconn.edu/sem/). These studies and field tests provided opportunities for the development of large amounts of practical know-how that are readily available for schools that would like to implement the SEM. They also have shown that the SEM can be implemented in a wide variety of settings with various populations of students including high ability students with learning disabilities, high ability students who underachieve, and schools that serve low-income students.

\section{School Structures of SEM}

The regular curriculum. The regular curriculum consists of everything that is a part of the predetermined goals, schedules, learning outcomes, and delivery systems of the school. The regular curriculum might be traditional, innovative, or in the process of transition, but its predominant feature is that authoritative forces (i.e., policy makers, school councils, textbook adoption committees, state regulators) have determined that the regular curriculum should be the "centerpiece" of student learning. Application of the SEM influences the regular curriculum in the differentiation of the challenge level of required material using curriculum compacting and the enrichment recommended in the Enrichment Triad Model (RENZULLI, 1977) integrated in regular curriculum activities. Although our goal in the SEM is to influence rather than replace the regular curriculum, the application of certain SEM components and related staff development activities has resulted in substantial changes in both the content and instructional processes of the entire regular curriculum.

The enrichment clusters. The enrichment clusters, a second component of the SEM, are non-graded groups of students who share common interests, and who come together during specially designated time blocks during school to work with an adult who shares their interests and who has some degree of advanced knowledge and expertise in the area. The enrichment clusters usually meet for a block of time weekly during a semester. All students complete an interest inventory developed to assess their interests, and an enrichment team of parents and teachers tally all of the major families of interests. Adults from the faculty, staff, parents, and community are recruited to facilitate enrichment clusters based on these interests, such as creative writing, drawing, sculpting, archeology and other areas. Training is provided to the 
facilitators who agree to offer the clusters, and a brochure is developed and sent to all parents and students that discusses student interests and select choices of enrichment clusters. Students select their top three choices for the clusters and scheduling is completed to place all children into their first, or in some cases, second choice. Like extracurricular activities and programs such as 4- $\mathrm{H}$ and Junior Achievement, the main rationale for participation in one or more clusters is that students and teachers want to be there. All teachers (including music, art, physical education, etc.) are involved in teaching the clusters; and their involvement in any particular cluster is based on the same type of interest assessment that is used for students in selecting clusters of choice.

The model for learning used with enrichment clusters is based on an inductive approach to solving real-world problems through the development of authentic products and services using the Enrichment Triad Model to create a learning situation with the use of specific methods, the development of higher order thinking skills, authentically applied to creative and productive situations. Enrichment clusters promote real-world problem solving, focusing on the belief that "every child is special if we create conditions in which that child can be a specialist within a specialty group" (RENZULLI, 1994, p. 70).

Enrichment clusters are organized around various characteristics of differentiated programming for gifted students on which the Enrichment Triad Model (Renzulli, 1977) was originally based, including the use of major disciplines, interdisciplinary themes, or cross-disciplinary topics (e.g., a theatrical/television production group that includes actors, writers, technical specialists, costume designers). The clusters are modeled after the ways in which knowledge utilization, thinking skills, and interpersonal relations take place in the real world. Thus, all work is directed toward the production of a product or service. Cluster facilitators do not prepare a detailed set of lesson plans or unit plans in advance; rather, direction is provided by three key questions addressed in the cluster by the facilitator and the students:

1. What do people with an interest in this area (e.g., film making) do?

2. What knowledge, materials, and other resources do they need to do it in an excellent and authentic way?

3. In what ways can the product or service be used to have an impact on an intended audience?

Enrichment clusters incorporate the use of advanced content and investigative methodology, providing students with information about particular fields of knowledge (RENZULLI 1988a). A focus is on using knowledge of the structures and tools of fields, as well as knowledge about the methods used to carry out investigations in particular fields. Enrichment clusters are not intended to be the total program for talent development in a school, or to replace existing programs for talented youth. Rather, they are one component of the SEM that can stimulate interests and develop talent in the entire school population. They can also serve as staff development 
opportunities as they provide teachers with an opportunity to participate in enrichment teaching, and subsequently to analyze and compare this type of teaching with traditional methods of instruction. In this regard the model promotes a spill-over effect by encouraging teachers to become better talent scouts and talent developers, and to apply enrichment techniques to general education classroom situations.

The continuum of special services. A broad range of special services is the third school structure targeted by the model, as represented in Figure 5. Although the enrichment clusters and the SEM-based modifications of the regular curriculum provide a broad range of services to meet individual needs, a program for total talent development still requires supplementary services that challenge our most academically talented young people who are capable of working at the highest levels. These services, which cannot ordinarily be provided in enrichment clusters or the regular curriculum, typically include: individual or small group counseling, acceleration, direct assistance in facilitating advanced level work, arranging for mentorships with faculty members or community persons, and making other types of connections between students, their families, and out-of-school persons, resources, and agencies.

Direct assistance also involves setting up and promoting student, faculty and parental involvement in special programs such as Future Problem Solving, Odyssey of the Mind, the Model United Nations program, and state and national essay competitions, mathematics, art, and history contests. Another type of direct assistance consists of arranging out-of-school involvement for individual students in summer programs, on-campus courses, special schools, theatrical groups, scientific expeditions, and apprenticeships at places where advanced level learning opportunities are available. Provision of these services is one of the responsibilities of the Schoolwide Enrichment teaching specialist or an enrichment team of teachers and parents who work together to provide options for advanced learning. Most Schoolwide Enrichment teaching specialists spend 2 days a week in a resource capacity to the faculty and 3 days providing direct services to students.

\section{New Directions in the SEM: Using Renzulli Learning ${ }^{\mathrm{TM}}$ to Provide Enriched, Differentiated Learning for All Students}

The Renzulli Learning System (RLS) is the newest component of the SEM. It is an interactive online program that aids in the implementation of SEM by matching student interests, expression styles and learning styles with a vast array of carefully selected and multiply tagged enrichment activities and resources, designed to enrich gifted and high potential students' learning process. Using Renzulli Learning ${ }^{\mathrm{TM}}$, students explore, discover, learn and create using the SEM married to the most current technology resources independently and in a safe environment. Renzulli Learning consists of a series of services that represent the various components of SEM. In an experimental control group research study (FIELD, 2009) examined achievement levels in students in grades $35(\mathrm{n}=185)$ and grades $68(\mathrm{n}=198)$ who were randomly assigned to use Renzulli Learning for 2-3 hours each week for a 16-week period. Students in the treatment groups were compared to students who did not have the opportunity to use Renzulli Learning in control classes in the same schools. 
A two-way repeated-measures ANOVA was used to explore differences between treatment and control students. After 16 weeks, students who participated in Renzulli Learning demonstrated significantly higher growth in reading comprehension $(\mathrm{p}<$ $.001)$, oral reading fluency $(\mathrm{p}=.016)$, and social studies achievement $(\mathrm{p}=.013)$ than those students who did not participate in Renzulli Learning.

The Renzulli Profiler is an interactive assessment tool that identifies students' academic strengths, interests, and preferred learning and expression styles. The computer-generated profile consists of carefully selected, user-friendly, research-based questions related to the areas mentioned above. The system assesses 13 major categories of student interests, 9 learning style preferences, and 10 specific expression style preferences. The assessment takes approximately 30-50 minutes (depending on reading and keyboarding skills), and produces an accurate, printable assessment of each student's interests, abilities, and how that individual best learns. The Profiler reflects the world of learning from the students' perspective, not necessarily that of their parents or teachers. This makes it possible to provide enrichment based on the Enrichment Triad Model with optimum effectiveness and efficiency. By representing the student's view, the Profiler becomes a major productivity tool for teachers-placing them literally months ahead in their efforts to understand each child's strengths, and to be able to respond to and incorporate those strengths into effective differentiation strategies.

The Renzulli Enrichment Database includes thousands of carefully screened, grade-level appropriate, child-safe enrichment opportunities that are regularly monitored, updated, enhanced and expanded at a rate of over 500 per month. The RLS Enrichment Database provides teachers with a vast storehouse of differentiated enrichment materials and resources for students with varying ability levels, interests, learning styles, and preferred styles of expression. To truly individualize and differentiate for students of various needs, teachers using the RLS have easy access to an unlimited supply of enrichment activities and resources that make such differentiation possible. The databases are organized into 14 separate categories, representing a wide range of educational activities. These include: Virtual Field Trips, Real Field Trips, Creativity Training Activities, Training in Critical Thinking, Independent Study Options, Contests and Competitions, Websites Based on Personalized Interests, High Interest Fiction Books, High Interest Non-Fiction Books, How-To Books for Conducting Research and Creative Projects, Summer Program Options in Special Talent Areas, On-Line Activities and Research Skills, Research Skills, Videos, and DVDs. All enrichment database entries are carefully researched by Renzulli Learning ${ }^{\mathrm{TM}}$ education specialists, screened for grade-level applicability, and coded as one of the 14 enrichment categories. Each activity is also tagged by state curriculum standards. Elements of each category are then matched to students' top three choices of interests, learning and product styles, providing each student with a unique personalized selection of enrichment opportunities. The search automatically links each student's Profile with the Enrichment Database to generate a customized list of activities designed to appeal to that student's grade level, interests, and abilities, as well as his or her learning and expression styles. 
Curriculum Connections, Super Starter Projects, The Assignment Maker, and Unit Supplements are additional features of the RLS that enables teachers to enter a set of one or more self-selected keywords by grade level, standard, topic, and subtopic to locate specific database entries that can be used in connection with almost any given unit of study.. A global search capability enables students and teachers to access the entire Enrichment Database, across all interests, expression styles, learning styles, or even grade levels. This permits students with above-grade capabilities to locate and pursue new activities and topics of interest, all within the safety of a prescreened information environment. It also helps teachers identify possible projects and other curriculum enhancements within the same space their students explore. The RLS combined search facilities offer children an extensive, expanding menu of learning opportunities, and offers teachers a new and valuable time saving resource for their classroom preparation.

The Total Talent Portfolio provides a complete record of the student's on-line learning activities and academic progress and an on-line portfolio to save students' best work. The Talent Portfolio enables students to create and post writings, Internet links, images, and other work on projects or areas of interest.

The Wizard Project Maker is an on-line project-management tool that helps students to create their own high interest projects and store them in their own Talent Portfolio. Over 200 Super Starter Projects in the Project Maker enable students to begin the process of doing investigative work on a small-scale, short term basis that may later enable them to initiate and complete their own projects more independently.

Renzulli Learning also offer a series of management tools for teachers, administrators and parents, designed to help follow individual students' learning progression, analyze group usage patterns, and formulate lesson plans and various approaches to classroom organization. The RLS features a collection of administrative reports designed to help make the process of enriching each student's learning process more efficient. These tools enable teachers, parents, and other mentors to learn more about their students and to make grouping and enrichment easier. Reports include printable listings of individual and group interests, and individual and group summaries of student expression styles and learning styles. Also available are teacher learning maps for enrichment differentiation activities; down-loadable enrichment projects; down-loadable creativity training activities; background articles by leading educational practitioners; lesson plans for using the RLS effectively; and outstanding websites for teachers.

These components provide both students and teachers with unique educational experiences, directly suited to each individual's learning profile, while simultaneously giving parents insights about their child's enrichment needs. Renzulli Learning $^{\mathrm{TM}}$ also helps all teachers better understand and know their students and thus meet their diverse needs. Perhaps the most significant aspect of the RLS is its emphasis on a student's strengths, celebrating and building upon students' academic abilities, and 
interests, in the tradition of SEM. This web-based on-line program matches students' interests, learning styles, expression styles, abilities and grade level to thousands of opportunities designed to provide enriched, challenging learning. It gives teachers a virtual equivalent of multiple "teaching assistants" in their classrooms-each and every day. Teachers can also access exciting web sites to help their own teaching and download creative activities to use in their classroom. They can monitor students' progress by accessing their profiles and viewing all of the activities and assessments that they have completed. Teachers using this system can even submit their own ideas for activities and interact with other teachers, enrichment specialists, curriculum coordinators, and administrators from around the country. Finally, parents can view their child's progress, his or her profile, and their choice of enrichment activities and projects.

\section{Non-negotiables in Implementing the SEM}

The many changes taking place in general education have resulted in some unusual reactions to the SEM that might best be described as the good news/bad news phenomenon. The good news is that many schools are expanding their conception of giftedness and they are more willing than ever to extend a broader continuum of services to larger proportions of the school population. The bad news is that the motivation for these changes is often based on mistaken beliefs (a) that we can adequately serve high potential students without some forms of grouping, (b) that we don't need special program teachers, or (c) that special program teachers are best utilized by going from classroom to classroom with a "shopping cart" of thinking skill lessons and activities.

\section{Non-negotiable \# 1}

The first non-negotiable is that anyone who tries to implement an SEM program has read our book entitled The Schoolwide Enrichment Model: A Comprehensive Plan for Educational Excellence (RENZULLI \& REIS, 1997). A thorough knowledge of the goals and components is essential.

\section{Non-negotiable \#2}

Although we have advocated a larger talent pool than traditionally has been the practice in gifted education, and a talent pool that includes students who gain entrance on both test and non-test criteria (Renzulli, 1988b), we firmly maintain that the concentration of services necessary for the development of high level potentials cannot take place without identifying and documenting individual student abilities. Targeting and documenting does not mean that we will simply play the same old game of classifying students as "gifted" or "not gifted," and let it go at that. Rather, targeting and documenting are part of an ongoing process that produces a comprehensive and always evolving "Total Talent Portfolio" about student abilities, interests, and learning styles (DUNN, DUNN, \& PRICE, 1977). The most important thing to keep in mind about this approach is that all information should be used to make individual programming decisions about present and future activities, and about 
ways in which we can enhance and build upon documented strengths. Documented information will enable us (a) to recommend enrollment in advanced courses or special programs (e.g., summer programs, college courses), and (b) it will provide direction in taking extraordinary steps to develop specific interests and resulting projects within topics or subject matter areas of advanced learning potential.

\section{Non-negotiable \#3}

Enrichment specialists (aka gifted education teachers) must devote a majority of their time to working directly with talent pool students, and this time mainly should be devoted to facilitating individual and small group investigations (i.e., Type IIIs). Some of their time with talent pool students can be devoted to stimulating interest in potential Type IIIs through advanced Type I experiences and advanced Type II training that focuses on learning research skills necessary to carry out investigations in various disciplines. To do this, we must encourage more classroom teachers to become involved in talent development through both enrichment opportunities and in curriculum modification and differentiation within their classrooms. We must also encourage more classroom teachers to participate in enrichment teams who work together to provide talent development opportunities for all students in the school, enabling the enrichment specialists to work with more advanced students.

\section{Non-negotiable \#4}

SEM programs must have specialized, trained personnel who work directly with talent pool students, to teach advanced courses and to coordinate enrichment services in cooperation with a school wide enrichment team. The old cliché, "Something that is the responsibility of everyone ends up being the responsibility of no one," has never been more applicable than when it comes to Enrichment or Gifted Education Specialists. The demands made upon general education classroom teachers, especially during these times of mainstreaming and heterogeneous grouping, leave precious little time to challenge our most able learners and to accommodate interests that clearly are above and beyond the regular curriculum. In a study completed by The National Research Center on the Gifted and Talented (WESTBERG, 1991), it was found that in $84 \%$ of general education classroom activities, no differentiation was provided for identified high ability students. Accordingly, time spent in enrichment programs with specialized teachers is even more important for high potential students.

Related to this non-negotiable are the issues of teacher selection and training, and the scheduling of special program teachers. Providing unusually high levels of challenge requires advanced training in the discipline(s) that one is teaching, in the application of process skills, and in the management and facilitation of individual and small group investigations. It is these characteristics of enrichment specialists rather than the mere grouping of students that have resulted in achievement gains and high levels of creative productivity on the parts of special program students.

Every profession is defined in part by its identifiable specializations, according to the task(s) to be accomplished. But specialization means more than the acquisition 
of particular skills. It also means affiliation with others who share common goals; the promotion of one's field; participation in professional activities, organizations, and research; and contributions to the advancement of the field. It also means the kinds of continued study and growth that make a difference between a job and a career. Now, more than ever, it is essential to fight for the special program positions that are falling prey to budget cuts. All professionals in the field should work for the establishment of standards and specialized certification for enrichment specialists. They should also help parents organize a task force that will be ready at a moment's notice to call in the support of every parent (past as well as present) whose child has been served in a special program.

\section{Conclusion}

There may never have been a time when so much debate about what should be taught has existed in American schools. The current emphasis on testing as connected to federal legislation, the standardization of curriculum, and the drive to increase achievement scores has produced major changes in education during the last two decades. Yet at the same time, our society continues to need to develop creativity in our students. As overpopulation, disease, war, pollution, and starvation increase both here and throughout the rest of the world, the need for creative solutions to these and other problems is clear. Enrichment programs have been the true laboratories of our nation's schools because they have presented ideal opportunities for testing new ideas and experimenting with potential solutions to long-standing educational problems. Programs for high potential students have been an especially fertile place for experimentation because such programs are usually not encumbered by prescribed curriculum guides or traditional methods of instruction. The SEM creates a repertoire of services that can be integrated in such a way to create "a rising tide lifts all ships" approach. The model includes a continuum of services, enrichment opportunities and three distinct services: curriculum modification and differentiation, enrichment opportunities of various types, and opportunities for the development of individual portfolios including interests, learning styles, product styles and other information about student strengths. Not only has this model been successful in addressing the problem of high potential students who have been under-challenged, it also provides additional important learning paths for creative students who achieve academic success in more traditional learning environments but long for innovative opportunities in school that are more than merely high speed text consumption.

The absence of opportunities to develop creativity in all young people, and especially in talented students, is arguably the biggest challenge in gifted education. In the SEM, students are encouraged to become responsible partners in their own education and to develop a passion and joy for learning. As students pursue creative enrichment opportunities, they learn to acquire communication skills and enjoy creative challenges. The SEM provides the opportunity for students to develop their gifts and talents and to begin the process of life-long learning, culminating in what we hope, will result in higher levels of creative and innovative work in their areas of interest and passion as adults. 


\section{References}

AMABILE, T. The social psychology of creativity. New York: Springer-Verlag, 1983.

BAUM, S. M. Learning disabled students with superior cognitive abilities: A validation study of descriptive behaviors. Tese de Doutorado, University of Connecticut, Storrs, 1985.

BAUM, S. M. An enrichment program for the gifted learning disabled students. Gifted Child Quarterly, v. 32, 1988, p. 226-230.

BRUNER, J. S. The process of education.Cambridge, MA: Harvard University Press, 1960.

BRUNER, J. S. Toward a theory of instruction. Cambridge, MA: Harvard University Press, 1966.

BURNS, D. E. The effects of group training activities on students' creative productivity. Tese de Doutorado, University of Connecticut, Storrs, 1987.

BURNS, D. E. SEM network directory. Storrs, CT: Neag Center for Gifted Education and Talent Development, University of Connecticut, 1998.

COOPER, C. Administrators' attitudes toward gifted programs based on the enrichment triad/revolving door identification model: Case studies in decision making. Tese de Doutorado, University of Connecticut, Storrs, 1983.

DELCOURT, M. A. B. Creative productivity among secondary school students: Combining energy, interest, and imagination. Gifted Child Quarterly, v. 37, 1993, p. 23-31.

DEWEY, J. Interest and effort in education. New York: Houghton Mifflin, 1913.

DEWEY, J. Democracy and education. New York: Macmillan, 1916.

DUNN, R.; DUNN, K.; PRICE, G. E. Diagnosing learning styles: Avoiding malpractice suits against school systems. Phi Delta Kappan, v. 58, 1977, p. 418-420.

ELECK, S. Students' perceptions of Renzulli Learning Systems. Trabalho de conclusão premiado, University of Connecticut, Storrs, 2006.

EMERICK, L. Academic underachievement among the gifted:Students' perceptions of factors relating to the reversal of the academic underachievement pattern. Tese de Doutorado, University of Connecticut, Storrs, 1988.

FIELD, G. B. The Effects of the Use of Renzulli Learning on Student Achievement in Reading Comprehension, Reading Fluency, Social Studies, and Science. International Journal of Emerging Technologies in Learning (iJET), v. 4, n. 1, 2009, p. 23-28.

GARDNER, H. Frames of mind: The theory of multiple intelligences. New York: Basic Books, 1983.

GUBBINS, E. J. (Ed.). Research related to the enrichment triad model (RM 95212). Storrs, CT: The National Research Center on the Gifted and Talented, University of Connecticut, 1995.

HEAL, M. M. Student perceptions of labeling the gifted: A comparative case study analysis. Tese de Doutorado, University of Connecticut, Storrs, 1989.

HÉBERT, T. P. Reflections at graduation: The long-term impact of elementary school experiences in creative productivity. Roeper Review, v. 16, 1993, p. 22-28.

IMBEAU, M. B. A. Teachers' attitudes toward curriculum compacting: A comparison of different inservice strategies. Tese de Doutorado, University of Connecticut, Storrs, 1991.

KARAFELIS, P. The effects of the tri-art drama curriculum on the reading comprehension of students with varying levels of cognitive ability. Tese de Doutorado, University of Connecticut, Storrs, 1986.

KETTLE, K.; RENZULLI, J. S.; RIZZA, M. G. Products of mind: Exploring student preferences for product development using My Way... An Expression Style Instrument. Gifted Child Quarterly, v. 42, 1998, p. 49-60.

JAMES, W. On the functions of cognition. Mind, v. 10, 1885, p. 27-44.

KIRSCHENBAUM, R. J. Let's cut out the cut-off score in the identification of the gifted. Roeper Review, v. 5, 1983, p. 6-10.

KIRSCHENBAUM, R. J.; SIEGLE, D. Predicting creative performance in an enrichment program. Artigo apresentado na $6^{a}$ Conferência Anual, Association for the Education of Gifted Underachieving Students, Portland, OR, abr. 1993. 
NEISSER, U. The concept of intelligence. In: STERNBERG, R. J.; DETTERMAN, D. K. (Eds.). Human intelligence, 179-189. Norwood, NJ: Ablex, 1979, p. 179-189.

NEWMAN, J. L. The effects of the Talents Unlimited model on students' creative productivity. (Tese de Doutorado) The University of Alabama, Tuscaloosa, 1991.

OLENCHAK, F. R. The schoolwide enrichment model in the elementary schools:A study of implementation stages and effects on educational excellence. In: RENZULLI, J. S. (Ed.), Technical report on research studies relating to the revolving door identification model. 2 ed., 201-247). Storrs, CT: Bureau of Educational Research, University of Connecticut. 1988, p. 201-247.

OLENCHAK, F. R.; RENZULLI, J. S. The effectiveness of the schoolwide enrichment model on selected aspects of elementary school change. Gifted Child Quarterly, v. 32, 1989, p. 44-57.

OLENCHAK, F. R. School change through gifted education: Effects on elementary students' attitudes toward learning. Journal for the Education of the Gifted, v. 14, 1990, p. 66-78.

PERLETH, C. H.; SIERWALD, W.; HELLER, K. A. Selected results of the Munich longitudinal study of giftedness: The multidimensional/typological giftedness model. Roeper Review, v. 15, 1993, p. 149-155.

PIAGET, J. The development of thought: Equilibration on of cognitive structures. New York: Viking, 1975.

REIS, S. M. An analysis of the productivity of gifted students participating in programs using the revolving door identification model. Tese de Doutorado, University of Connecticut, Storrs, 1981.

REIS, S. M.; BURNS, D. E.; RENZULLI, J. S. Curriculum compacting: The complete guide to modifying the regular curriculum for high ability students. Mansfield Center, CT: Creative Learning Press, 1992.

REIS, S. M.; ECKERT, R. D.; SCHREIBER, F. J.; JACOBS, J.; BRIGGS, C. ; GUBBINS, E. J., et al. (2005). The schoolwide enrichment model reading study (RM05214).Storrs, CT: The National Research Center on the Gifted and Talented, University of Connecticut, 2005.

REIS, S. M.; GENTRY, M.; MAXFIELD, L. R. The application of enrichment clusters to teachers' classroom practices. Journal for the Education of the Gifted, v. 21, 1998, p. 310-324.

REIS, S. M.; RENZULLI, J. S. A case for the broadened conception of giftedness. Phi Delta Kappan, v. 64, 1982, p. 619-620.

REIS, S. M.; SCHADER, R.; MILNE, H.; STEPHENS, R. Music \& minds: Using a talent development approach for young adults with Williams syndrome. Exceptional Children, v. 69, 2003, p. 293-314.

REIS, S. M.; WESTBERG, K. L.; KULIKOWICH, J.; CAILLARD, F.; HÉBERT, T. P.; PLUCKER, J. A., et al. (1993). Why not let high ability students start school in January? The curriculum compacting study (Research Monograph 93106). Storrs, CT: The National Research Center on the Gifted and Talented, University of Connecticut, 1993.

REIS, S. M.; WESTBERG, K. L.; KULIKOWICH, J.; PURCELL, J. H. Curriculum compacting and achievement test scores: What does the research say? Gifted Child Quarterly, v. 42, 1998, p. 123-129.

RENZULLI, J. S. The enrichment triad model: A guide for developing defensible programs for the gifted and talented. Gifted Child Quarterly, v. 20, 1976, p. 303-326.

RENZULLI, J. S. The enrichment triad model: A guide for developing defensible programs for the gifted and talented. Mansfield Center, CT: Creative Learning Press, 1977.

RENZULLI, J. S. What makes giftedness? Re-examining a definition. Phi Delta Kappan, v. 60, 1978, p. 184261.

RENZULLI, J. S. What makes a problem real:Stalking the illusive meaning of qualitative differences in gifted education. Gifted Child Quarterly, v. 26, 1982, p. 147-156.

RENZULLI, J. S. The three ring conception of giftedness:A developmental model for creative productivity.In: STERNBERG, R. J. ; DAVIDSON, J. E. (Eds.). Conceptions of giftedness 53-92). New York: Cambridge University Press, 1986, p. 53-92.

RENZULLI, J. S. The multiple menu model for developing differentiated curriculum for the gifted and talented. Gifted Child Quarterly, v. 32, 1988a, p. 298-309.

RENZULLI, J. S. (1988b). Technical report of research studies related to the enrichment triad/revolving door model .3 ed.Storrs, CT: Teaching the Talented Program, University of Connecticut, 1988b. 
RENZULLI, J. S. Schools for talent development: A practical plan for total school improvement. Mansfield Center, CT: Creative Learning Press, 1994.

RENZULLI, J. S. The three ring conception of giftedness. In: STERNBERG, R. J.; DAVIDSON, J. E. (Eds.). Conceptions of giftedness. 2 ed. 246-79). New York: Cambridge University Press, 2005, p. 246-279.

RENZULLI, J. S; REIS, S. M. The schoolwide enrichment model: A comprehensive plan for educational excellence. Mansfield Center, CT: Creative Learning Press, 1985.

RENZULLI, J. S; REIS, S. M. Research related to the schoolwide enrichment model. Gifted Child Quarterly, v. 38, 1994, p. 2-14.

RENZULLI, J. S; REIS, S. M. The schoolwide enrichment model: A how-to guide for educational excellence (2nd ed.). Mansfield Center, CT: Creative Learning Press, 1997.

RENZULLI, J. S; REIS, S. M.; SMITH, L. H. The revolving door identification model. Mansfield Center, CT: Creative Learning Press, 1981.

RENZULLI, J. S.; SMITH, L. H. The compactor. Mansfield Center, CT: Creative Learning Press, 1978.

RENZULLI, J. S; SMITH, L. H.; REIS, S. M. Curriculum compacting: An essential strategy for working with gifted students. The Elementary School Journal, v. 82, 1982, p. 185-194.

SCHACK, G. D. Creative productivity and self-efficacy in children. Tese de Doutorado, University of Connecticut, Storrs, 1985.

STARKO, A. J. The effects of the revolving door identification model on creative productivity and self-efficacy. Tese de Doutorado, University of Connecticut, Storrs, 1986.

STERNBERG, R. J. Toward a triarchic theory of human intelligence. Behavioral and Brain Sciences, v. 7 , 1984, p. 269-287.

STERNBERG, R. J. Three facet model of creativity. In: STERNBERG, R. J (Ed.), The nature of creativity 125-147). Boston: Cambridge University Press, 1988, p. 125-147.

STERNBERG, R. J. Thinking styles: Keys to understanding student performance. Phi Delta Kappan, v. 71, 1990, p. 366-371.

STERNBERG, R. J.; DAVIDSON, J. E. (Eds.). Conceptions of giftedness. New York: Cambridge University Press, 1986.

STERNBERG, R. J.; DAVIDSON, J. E. (Eds.). (2005). Conceptions of giftedness. 2 ed. New York: Cambridge University Press, 2005.

TAYLOR, L. A. The effects of the secondary enrichment triad model and a career counseling component on the career development of vocational-technical school students. Tese de Doutorado, University of Connecticut, Storrs, 1992

THORNDIKE, E. L. Intelligence and its measurement. Journal of Counseling Psychology, v. 12, 1921, p. 124-127.

TORRANCE, E. P. Guiding creative talent. Englewood Cliffs, NJ: Prentice-Hall, 1962.

TORRANCE, E. P. Norms-Technical manual:Torrance tests of creative thinking. Bensenville, IL: Scholastic Testing Service, 1974.

WARD, V. S. Systematic intensification and extensification of the school curriculum. Exceptional Children, v. 28,1960 , p. $67-71$.

WESTBERG, K. L. The effects of instruction in the inventing process on students' development of inventions. Tese de Doutorado, University of Connecticut, Storrs, 1991.

WESTBERG, K. L. Guiding students' independent projects. Pre-convention Institute of the annual convention of the National Association for Gifted Children, Denver, 2002.

\section{Nota}

${ }^{1}$ It is beyond the scope of this chapter to review the work of these eminent theorists and thinkers; the main concepts or ideas that each person has contributed to this approach to learning can be found in Schools for Talent Development (RENZULLI, 1994, p. 203) 
Joseph Renzulli

\section{Correspondência}

Joseph Renzulli - 2131 Hillside Road, The University of Connectiut, Storrs, CT: 06269. - United States of America.

E-mail: joseph.renzulli@uconn.edu

Recebido em 14 de outubro de 2013

Aprovado em 06 de junho de 2014 